\title{
Stereoselective syntheses of 3-aminocyclooctanetriols and halocyclooctanetriols
}

\author{
Emine Salamci ${ }^{*}$ and Yunus Zozik
}

\author{
Full Research Paper \\ Address: \\ Department of Chemistry, Faculty of Sciences, Atatürk University, \\ 25240 Erzurum, Turkey \\ Email: \\ Emine Salamci* - esalamci@atauni.edu.tr \\ * Corresponding author \\ Keywords: \\ aminocyclitols; aminocyclooctanetriol; chlorocyclooctanetriol; cyclic \\ sulfate; cyclitols
}

\author{
Beilstein J. Org. Chem. 2021, 17, 705-710. \\ https://doi.org/10.3762/bjoc.17.59 \\ Received: 13 December 2020 \\ Accepted: 26 February 2021 \\ Published: 11 March 2021 \\ Associate Editor: S. Bräse \\ (C) 2021 Salamci and Zozik; licensee Beilstein-Institut. \\ License and terms: see end of document.
}

\begin{abstract}
The efficient synthesis of two new stereoisomeric 3-aminocyclooctanetriols and their new halocyclitol derivatives starting from cis, cis-1,3-cyclooctadiene are reported. Reduction of cyclooctene endoperoxide, obtained by photooxygenation of $c i s, c i s-1,3-$ cyclooctadiene, with zinc yielded a cyclooctene diol followed by acetylation of the hydroxy group, which gave dioldiacetate by $\mathrm{OsO}_{4} / \mathrm{NMO}$ oxidation. The cyclooctane dioldiacetate prepared was converted to the corresponding cyclic sulfate via the formation of a cyclic sulfite in the presence of catalytic $\mathrm{RuO}_{4}$. The reaction of this cyclic sulfate with a nucleophilic azide followed by the reduction of the azide group provided the target, 3-aminocyclooctanetriol. The second key compound, bromotriol, was prepared by epoxidation of the cyclooctenediol with $m$-chloroperbenzoic acid followed by hydrolysis with $\mathrm{HBr}(\mathrm{g})$ in methanol. Treatment of bromotriol with $\mathrm{NaN}_{3}$ and the reduction of the azide group yielded the other desired 3-aminocyclooctanetriol. Hydrolysis of the epoxides with $\mathrm{HCl}(\mathrm{g})$ in methanol gave stereospecifically new chlorocyclooctanetriols.
\end{abstract}

\section{Introduction}

The synthesis of aminocyclitols has attracted attention because they contain substructures of many biologically active natural products [1-3]. They have become important structural components for drug development with a modifying action as inhibitors of glycosidases [4-10]. Aminocyclitols are amino polyhydroxy cycloalkanes [2] formally derived from cyclitols [11-15], which are polyhydroxylated cycloalkanes, via replacement of one of the hydroxy groups with an amino group. Many aminocyclitols and their derivatives have been found to possess antibiotic properties, such as validamycins (1) [16]. Validamycin A (1) contains two aminocyclitol units, the one is valienamine (2) and the other is validamine (3, Figure 1).

One of the most important conduramines $\mathbf{4}$ is valienamine (3) [17], which is found as a building block in several aminoglycoside antibiotics [2]. Furthermore, conduramines $\mathbf{4}$ and their de- 
<smiles>OCC1=CC(NC2CC(CO)C(OC3OC(CO)C(O)C(O)C3O)C(O)C2O)C(O)C(O)C1O</smiles><smiles>N[C@H]1C=C(CO)C(O)[C@H](O)[C@H]1O</smiles>

valienamine (2)<smiles>N[C@H]1CC(CO)C(O)[C@H](O)[C@H]1O</smiles>

validamine (3)<smiles>NC1C(O)C=CC(O)C1O</smiles>

conduramine (4)

Figure 1: Structures of some important aminocyclitols.

rivatives are used as both inhibitors of glycosidases and useful intermediates in organic synthesis [18]. Halocyclitols are also cyclitol derivatives, in which one of the hydroxy groups is replaced by a halogen. They have also attracted interest in the last decade because of their biological activities [11,19]. For instance, some brominated quercitol (cyclohexanepentol) derivatives and bromoconduritol-B act as strong inhibitors of $\alpha$-glycosidases [11,19]. Recent reviews report on the latest synthetic methodologies for aminocyclitols and related compounds [1-3,16].

Many methods have been previously reported for the synthesis of aminocyclitols containing five- and six-membered rings, along with their diverse biological activities [1-3,16-26]. However, only a limited number of synthetic methods are available for the synthesis of seven- [27,28], eight- [29-38], and nine[35] membered aminocyclitols. Therefore, we were inspired to

work on the development of the first synthesis of some C8-amino- and chloro-substituted cyclitols. Recently, we developed the first synthesis of various C8-amino- [29,31] and diaminocyclitol derivatives [30]. As part of our work involving the synthesis of C8-cyclitols, we report the stereospecific syntheses of two new 3-aminocyclooctanetriols and some chlorinated C8-cyclitols starting from cis,cis-1,3-cyclooctadiene.

\section{Results and Discussion}

For the synthesis of amino- and chlorocyclitols and their derivatives, we first selected endoperoxide $\mathbf{5}$ as the starting molecule, which was prepared using a procedure described in the literature [33] (Scheme 1). Among the most relevant precursors for the synthesis of aminocyclitols are cyclic sulfates $[36,37,39,40]$ and they have been also used in the synthesis of C8-aminocarbasugars [36,37] recently. We envisioned that aminotriol 12 could be prepared by the reaction with sodium azide of the corresponding cyclic sulfate intermediate $\mathbf{9}$, which contains the only stereocentre. The cyclic sulfate $\mathbf{9}$ could be synthesized from diacetatediol 7 [33].

For this purpose, the reduction of the endoperoxide 5 with zinc followed by acetylation of the hydroxy group and $\mathrm{OsO}_{4} / \mathrm{NMO}$ oxidation of the double bond gave diacetatediol 7 [33]. Treatment of diacetatediol 7 with thionyl chloride in pyridine gave the corresponding cyclic sulfite 8 in $95 \%$ yield (Scheme 1). Oxidation of the cyclic sulfite $\mathbf{8}$ with sodium periodate in the presence of ruthenium trichloride provided the corresponding cyclic sulfate 9 in $95 \%$ yield.

The cyclic sulfate moiety in $\mathbf{9}$ was reacted with sodium azide in $\mathrm{DMF}$ at $80^{\circ} \mathrm{C}$ followed by acidic hydrolysis of the resulting acyclic sulfate ester to give azidotriol $\mathbf{1 0}$ as a single stereoiso-

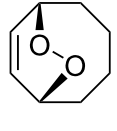

$\frac{\text { 1) } \mathrm{Zn}, \mathrm{AcOH}}{\text { 2) } \mathrm{Ac}_{2} \mathrm{O} \text {, pyridine }}$

5

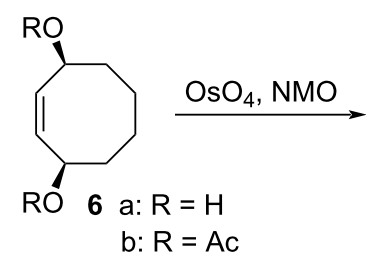

b: $R=A c$<smiles>[Z]OC1CCCC(O)C(O)C1O</smiles>

$\mathrm{SOCl}_{2}$, pyridine

$\mathrm{CH}_{2} \mathrm{Cl}_{2}, 0{ }^{\circ} \mathrm{C}, 2 \mathrm{~h}$

rt $19 \mathrm{~h}, 95 \%$<smiles>CC(C)(C)O[C@H]1CCCC[C@@H](O)[C@@H]2OS(=O)(=O)O[C@@H]12</smiles>

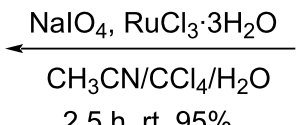<smiles>CC(=O)O[C@@H]1CCCC[C@H](OC(C)(C)C)[C@H]2OS(=O)O[C@H]12</smiles>

Scheme 1: Synthesis of cyclic sulfate 9 
mer in $97 \%$ yield (Scheme 2). For further structural proof, the azidotriol $\mathbf{1 0}$ was converted into the corresponding triacetate $\mathbf{1 1}$ with acetic anhydride in pyridine and 4-(dimethylamino)pyridine (DMAP) (yield 76\%). To determine the exact configurations of the substituents in 11, we made full assignments for the H-3 and the acetoxy protons with the help of the 1D and 2D NMR experiments. First, protons H-3 and H-1 in the triacetate $\mathbf{1 1}$ were irradiated separately at their resonance frequencies and the changes in the spectrum were observed. Upon irradiation at the resonance frequency of the proton $\mathrm{H}-3$ at $3.87 \mathrm{ppm}$ there is no change in the multiplet at $5.04-4.97 \mathrm{ppm}$. However, in the multiplet part at $5.24-5.15 \mathrm{ppm}$, some splittings disappeared. This experiment clearly shows that the proton $\mathrm{H}-3$ has couplings to both acetoxy protons $\mathrm{H}-2$ and $\mathrm{H}-4$. Furthermore, the proton $\mathrm{H}-3$ resonates as a doublet of doublets with coupling constants of $J=8.8$ and $2.7 \mathrm{~Hz}$, clearly indicating that $\mathrm{H}-3$ and $\mathrm{H}-2$ with a large coupling constant $\left(J_{2,3}=\right.$ $8.8 \mathrm{~Hz})$ are trans to each other. The small coupling constant $\left(J_{3,4}=2.7 \mathrm{~Hz}\right)$ between $\mathrm{H}-3$ and $\mathrm{H}-4$ shows the cis relationship between those protons. The configuration of the azide group in $\mathbf{1 1}$ was also confirmed by the cross peak between the proton $\mathrm{H}-3$ and the protons $\mathrm{H}-2$ and $\mathrm{H}-4$ in the COSY spectrum. Moreover, the fact that the proton $\mathrm{H}-3$ gives positive NOE clearly indicates that the proton $\mathrm{H}-3$ should have a cis configuration relative to the proton $\mathrm{H}-1$. On the other hand, the fact that the proton $\mathrm{H}-1$ gives a positive NOE's clearly indicates that the
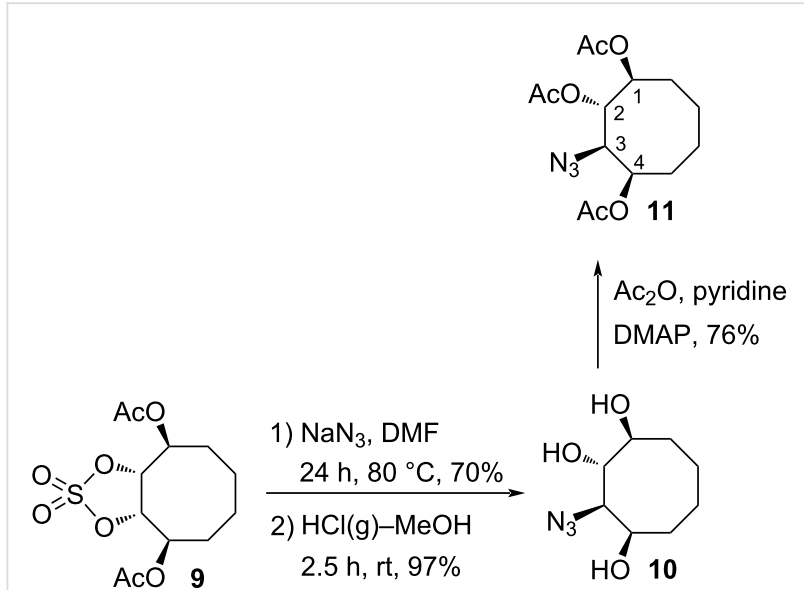

1) $\mathrm{NaN}_{3}, \mathrm{DMF}$

$24 \mathrm{~h}, 80^{\circ} \mathrm{C}, 70 \%$

2) $\mathrm{HCl}(\mathrm{g})-\mathrm{MeOH}$

$2.5 \mathrm{~h}, \mathrm{rt}, 97 \%$
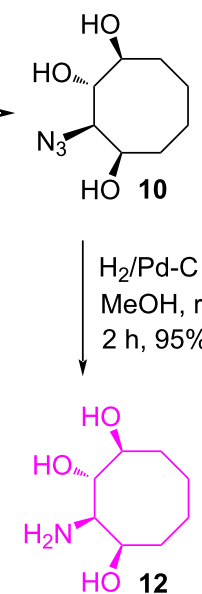

Scheme 2: Synthesis of aminocyclooctanetriol 12. proton $\mathrm{H}-1$ should have a cis configuration relative to the protons $\mathrm{H}-3$ and H-4. Next, the reduction of azidotriol $\mathbf{1 0}$ by hydrogenation afforded the target aminotriol 12 in $95 \%$ yield.

For the synthesis of the other aminocyclooctanetriol 18, the diol 6a [33] was reacted with $m$-CPBA to give trans-epoxide isomer 13 [33] (79\% yield) as the sole product (Scheme 3). Ring opening of trans-epoxide 13 by $\mathrm{HBr}(\mathrm{g})-\mathrm{MeOH}$ gave bromotriol 14, which is an ideal substrate for the synthesis of the aminocyclooctanetriol 18. For structural proof, bromotriol 14 was converted into the corresponding acetate $\mathbf{1 5}$ using $\mathrm{Ac}_{2} \mathrm{O}$ in pyridine and DMAP (81\%).

Next, to introduce the azido group in a cis-configuration, the bromotriol 14 was treated with sodium azide in DMF at $100{ }^{\circ} \mathrm{C}$ to afford azidotriol $\mathbf{1 6}$ as a single product in $78 \%$ yield. Com-
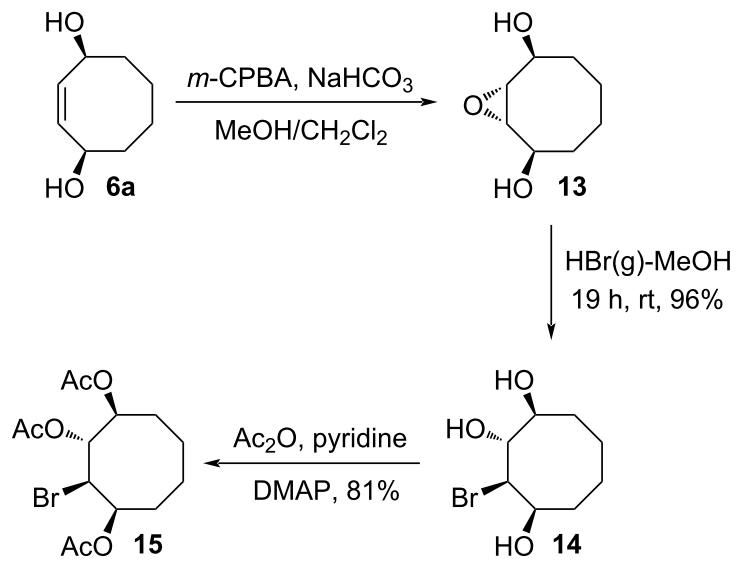<smiles>O[C@H]1CCCC[C@@H](O)[C@H](O)[C@@H]1Br</smiles>
$\mathrm{NaN}_{3}(8.0$ equiv)
$\mathrm{DMF}, 100{ }^{\circ} \mathrm{C}$
$28 \mathrm{~h}, 78 \%$

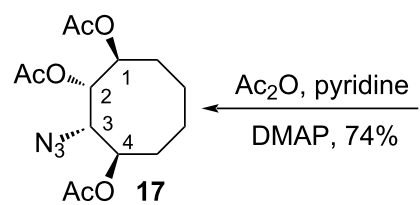<smiles>N[C@H]1[C@@H](O)CCCC[C@@H](O)[C@@H]1O</smiles>

$\mathrm{H}_{2} / \mathrm{Pd}-\mathrm{C}(10 \%)$ $\mathrm{MeOH}, 2$ h, rt $97 \%$

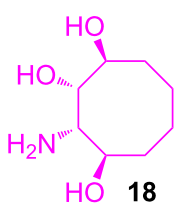

Scheme 3: Synthesis of aminocyclooctanetriol 18 
pound $\mathbf{1 6}$ was transformed into the corresponding triacetate $\mathbf{1 7}$ for full characterization of the structure (Scheme 3). The position of the azide group in $\mathbf{1 7}$ was confirmed by the help of the COSY spectrum. The diagonal peak at $3.95 \mathrm{ppm}$ has cross peaks with the protons resonating at 4.96 and $5.47 \mathrm{ppm}$, respectively. Analysis of these cross peaks shows that the cross peak at $5.47 \mathrm{ppm}$ is weaker. This weak correlation is due to the small coupling constant $(J=2.2 \mathrm{~Hz})$. On the other hand, the resonance signal of H-3 appears as a doublet of doublets at $3.95 \mathrm{ppm}$ with coupling constants of $J=8.6$ and $2.2 \mathrm{~Hz}$. The large coupling constant $(J=8.6 \mathrm{~Hz})$ clearly supports the trans relation of the protons $\mathrm{H}-3$ and $\mathrm{H}-4$ and the small coupling constant $(J=2.2 \mathrm{~Hz})$ the $c i s$ relation of the protons $\mathrm{H}-3$ and $\mathrm{H}-2$. Finally, the desired aminocyclooctanetriol 18 was obtained by hydrogenation of the azide functionality in compound $\mathbf{1 6}$ in $97 \%$ yield.

In the second part of this work, we turned our attention to the stereospecific synthesis of chlorocyclooctanetriol 19 starting from the trans-epoxide $\mathbf{1 3}$ (Scheme 4). The hydroxy groups in $\mathbf{1 9}$ were acetylated to give $\mathbf{2 0}$ for further characterization of the structure. The position of the chlorine atom in $\mathbf{2 0}$ was confirmed with the help of the COSY spectra. The resonance signal of H-3 appears as a doublet of doublets at $4.35 \mathrm{ppm}$ with coupling constants of $J=9.0$ and $2.5 \mathrm{~Hz}$. The large coupling constant $(J=9.0 \mathrm{~Hz})$ clearly supports the trans relation of the protons $\mathrm{H}-3$ and $\mathrm{H}-2$ and the small coupling constant $(J=$ $2.5 \mathrm{~Hz}$ ) the cis relation of the protons $\mathrm{H}-3$ and $\mathrm{H}-4$.
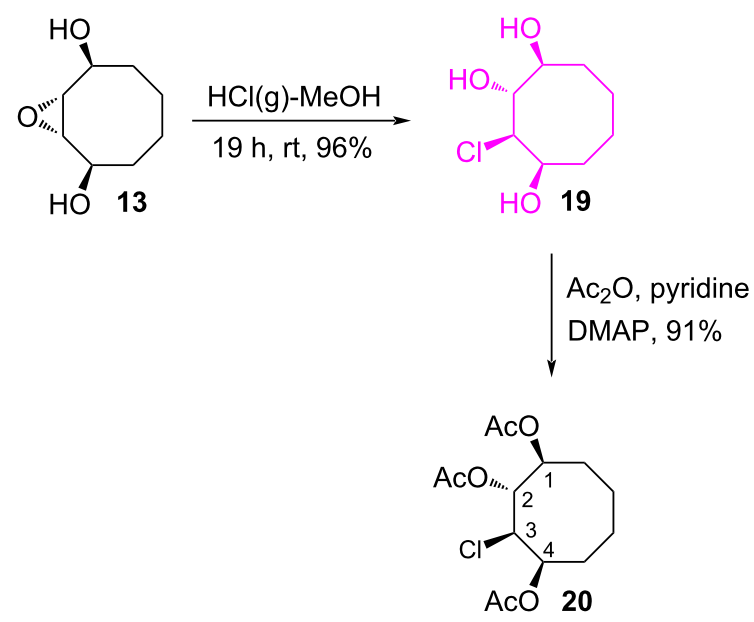

Scheme 4: Synthesis of chlorocyclooctanetriol 20.

As an alternate method for the synthesis of a novel chlorocyclooctanetriol isomer, epoxy-diol 22, which was synthesized in our previous work [31], was hydrolysed by $\mathrm{HCl}(\mathrm{g})$ in $\mathrm{MeOH}$, resulting in the formation of two chlorocyclooctanetriol isomers 23 and 24 in an 85:15 ratio ( ${ }^{1} \mathrm{H}$ NMR) in 96\% combined yield
(Scheme 5). Chlorotriols $\mathbf{2 3}$ and $\mathbf{2 4}$ were transformed into the corresponding triacetates $\mathbf{2 5}$ and $\mathbf{2 6}$ for full characterization of their structures. A mixture of isomeric triacetates $\mathbf{2 5}$ and $\mathbf{2 6}$ was isolated by column chromatography in $74 \%$ and $12 \%$ yields, respectively. The structures and configurations of these compounds were assigned using ${ }^{1} \mathrm{H}$ NMR and 2D NMR spectroscopic data. The position of the chlorine atom in $\mathbf{2 5}$ was confirmed with the help of the COSY spectra. The diagonal peak at $4.26 \mathrm{ppm}$ has cross peaks with the protons resonating at 2.15 and $5.62 \mathrm{ppm}$, respectively. Analysis of these cross peaks shows that the cross peak at $5.62 \mathrm{ppm}$ is strong. This strong correlation is due to the large coupling constant $(J=8.7 \mathrm{~Hz})$. The fact that the proton $\mathrm{H}-4$ appears as a doublet of doublet of doublets with coupling constants of $J=13.1, J=8.7$, and $3.3 \mathrm{~Hz}$ also supports the trans relation $(J=8.7 \mathrm{~Hz})$ of the protons $\mathrm{H}-4$ and $\mathrm{H}-3$. Similarly, the configuration of the chlorine atom and the acetoxy groups in $\mathbf{2 6}$ was determined with ${ }^{1} \mathrm{H}$ NMR and COSY spectra. Finally, deacetylation of chlorotriacetates $\mathbf{2 5}$ and $\mathbf{2 6}$

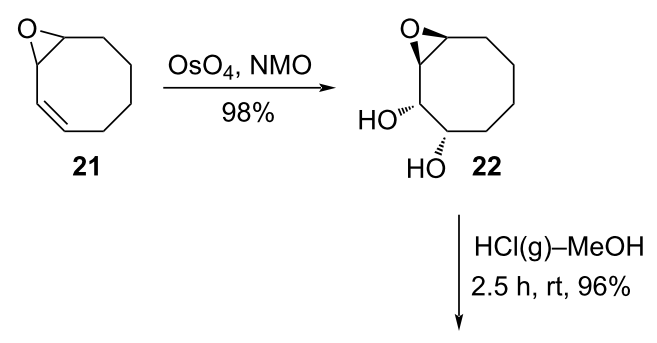<smiles>OC1CCCC(Cl)C(O)C1O</smiles><smiles>[Z4][C@H]1CCC[C@@H](O)[C@H](Cl)[C@H](O)[C@@H]1O</smiles>
$\mathrm{Ac}_{2} \mathrm{O}$, pyridine
DMAP, $90 \%$

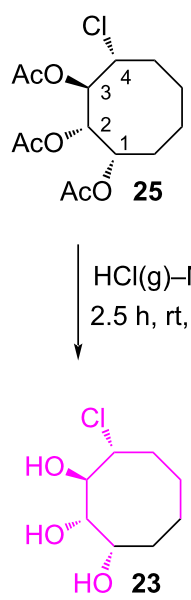<smiles>CC(=O)OC1CCCCC(OC(C)=O)C(OC(C)=O)C1Cl</smiles>

$(85: 15)$ $\mathrm{AcO} 26$ $\mathrm{HCl}(\mathrm{g})-\mathrm{MeOH}$ $2.5 \mathrm{~h}, \mathrm{rt}, 95 \%$

Scheme 5: Synthesis of chlorocyclooctanetriols 23 and 24. 
was carried out with $\mathrm{HCl}(\mathrm{g})$ in $\mathrm{MeOH}$ to give the free chlorotriols derivatives $\mathbf{2 3}$ and $\mathbf{2 4}$.

\section{Conclusion}

The synthesis of two stereoisomeric 3-aminocyclooctanetriols 12 and 18 and their halocyclitol derivatives 14, 19, 23, and 24 was achieved for the first time concisely and efficiently from cis,cis-1,3-cyclooctadiene. The nitrogen functionalities were introduced by the substitution with $\mathrm{NaN}_{3}$ of the corresponding cyclic sulfate and bromo groups, while the halogen functionality was introduced to the molecule by opening of the epoxide ring with $\mathrm{HBr}(\mathrm{g})$ or $\mathrm{HCl}(\mathrm{g})$ in $\mathrm{MeOH}$.

\section{Supporting Information}

\section{Supporting Information File 1}

Experimental section, ${ }^{1} \mathrm{H}$ and ${ }^{13} \mathrm{C}$ NMR spectra for all new compounds, as well as selected 2D NMR spectra. [https://www.beilstein-journals.org/bjoc/content/ supplementary/1860-5397-17-59-S1.pdf]

\section{Acknowledgements}

We would like to thank Professor Cavit Kazaz for performing the 2D NMR spectroscopy.

\section{Funding}

The authors are indebted to the Department of Chemistry (Atatürk University) and the Scientific and Technological Research Council of Turkey (TUBITAK, Grant No. TBAG110T208) for their financial support of this work.

\section{ORCID ${ }^{\circledR}$ iDs}

Emine Salamci - https://orcid.org/0000-0003-2828-6154 Yunus Zozik - https://orcid.org/0000-0002-6742-0443

\section{Preprint}

A non-peer-reviewed version of this article has been previously published as a preprint: https://doi.org/10.3762/bxiv.2020.142.v1

\section{References}

1. Salamci, E. Tetrahedron Lett. 2020, 61, 151728. doi:10.1016/j.tetlet.2020.151728

2. Diaz, L.; Delgado, A. Curr. Med. Chem. 2010, 17, 2393-2418. doi:10.2174/092986710791698512

3. Donaldson, W. A. ARKIVOC 2018, No. 4, 231-256. doi:10.24820/ark.5550190.p010.450

4. Ashry, E. E.; Rashed, N.; Shobier, A. H. S. Pharmazie 2000, 55, 331-348.
5. Donohoe, T. J.; Flores, A.; Bataille, C. J. R.; Churruca, F. Angew. Chem., Int. Ed. 2009, 48, 6507-6510. doi:10.1002/anie.200902840 Angew. Chem. 2009, 121, 6629-6632. doi:10.1002/ange.200902840

6. Griffen, J. A.; White, J. C.; Kociok-Köhn, G.; Lloyd, M. D.; Wells, A.; Arnot, T. C.; Lewis, S. E. Tetrahedron 2013, 69, 5989-5997. doi:10.1016/j.tet.2013.04.033

7. Ji, L.; Zhang, D.-f.; Zhao, Q.; Hu, S.-m.; Qian, C.; Chen, X.-Z. Tetrahedron 2013, 69, 7031-7037. doi:10.1016/j.tet.2013.06.046

8. Trapero, A.; González-Bulnes, P.; Butters, T. D.; Llebaria, A. J. Med. Chem. 2012, 55, 4479-4488. doi:10.1021/jm300342q

9. Lo, H.-J.; Chang, Y.-K.; Yan, T.-H. Org. Lett. 2012, 14, 5896-5899. doi:10.1021/ol3028237

10. Ghosal, P.; Shaw, A. K. J. Org. Chem. 2012, 77, 7627-7632. doi:10.1021/j0300804d

11. Aydin, G.; Savran, T.; Aktaş, F.; Baran, A.; Balci, M. Org. Biomol. Chem. 2013, 11, 1511-1524. doi:10.1039/c3ob26909d

12. Gültekin, M. S.; Salamci, E.; Balci, M. Carbohydr. Res. 2003, 338, 1615-1619. doi:10.1016/s0008-6215(03)00256-8

13. Salamci, E.; Seçen, H.; Sütbeyaz, Y.; Balci, M. J. Org. Chem. 1997, 62, 2453-2457. doi:10.1021/j0962092+

14. Salamci, E.; Seçen, H.; Sütbeyaz, Y.; Balci, M. Synth. Commun. 1997, 27, 2223-2234. doi:10.1080/00397919708003375

15. Seçen, H.; Salamci, E.; Sütbeyaz, Y.; Balci, M. Synlett 1993, 609-610. doi:10.1055/s-1993-22550

16. Delgado, A. Eur. J. Org. Chem. 2008, 3893-3906. doi:10.1002/ejoc.200800238

17. Chen, X.; Fan, Y.; Zheng, Y.; Shen, Y. Chem. Rev. 2003, 103, 1955-1978. doi:10.1021/cr0102260

18. Kim, J.-S.; Kang, J.-C.; Yoo, G.-H.; Jin, X.; Myeong, I.-S.; Oh, C.-Y.; Ham, W.-H. Tetrahedron 2015, 71, 2772-2776. doi:10.1016/j.tet.2014.12.071

19. Cantekin, S.; Baran, A.; Çalışkan, R.; Balci, M. Carbohydr. Res. 2009, 344, 426-431. doi:10.1016/j.carres.2008.12.005

20. Łysek, R.; Schütz, C.; Favre, S.; O'Sullivan, A. C.; Pillonel, C.; Krülle, T.; Vogel, P. Bioorg. Med. Chem. 2006, 14, 6255-6282. doi:10.1016/j.bmc.2006.05.080

21. Harit, V. K.; Ramesh, N. G. J. Org. Chem. 2016, 81, 11574-11586. doi:10.1021/acs.joc.6b01790

22. Trost, B. M.; Malhotra, S. Chem. - Eur. J. 2014, 20, 8288-8292. doi:10.1002/chem.201402175

23. Rajender, A.; Rao, B. V. Tetrahedron Lett. 2013, 54, 2329-2331. doi:10.1016/j.tetlet.2013.02.046

24. Łysek, R.; Favre, S.; Vogel, P. Tetrahedron 2007, 63, 6558-6572. doi:10.1016/j.tet.2007.03.149

25. Li, Q. R.; Kim, S. I.; Park, S. J.; Yang, H. R.; Baek, A. R.; Kim, I. S.; Jung, Y. H. Tetrahedron 2013, 69, 10384-10390. doi:10.1016/j.tet.2013.09.098

26. Ekmekci, Z.; Balci, M. Eur. J. Org. Chem. 2012, 4988-4995. doi:10.1002/ejoc.201200582

27. Shing, T. K. M.; Wong, W. F.; Ikeno, T.; Yamada, T. Org. Lett. 2007, 9, 207-209. doi:10.1021/ol0626210

28. Gravier-Pelletier, C.; Maton, W.; Dintinger, T.; Tellier, C.; Le Merrer, Y. Tetrahedron 2003, 59, 8705-8720. doi:10.1016/j.tet.2003.09.049

29. Karavaizoglu, U. N.; Salamci, E. New J. Chem. 2020, 44, 17976-17983. doi:10.1039/d0nj02697b

30. Zozik, Y.; Salamci, E.; Kilic, A. Tetrahedron Lett. 2017, 58, 4822-4826. doi:10.1016/j.tetlet.2017.11.014

31. Ecer, K.; Salamci, E. Tetrahedron 2014, 70, 8389-8396. doi:10.1016/j.tet.2014.08.060 
32. Kaya, A. A.; Salamci, E.; Menzek, A.; Erdem, S. S.; Şahin, E.; Ecer, K. Tetrahedron 2017, 73, 5381-5388. doi:10.1016/j.tet.2017.07.040

33. Salamci, E. Tetrahedron 2010, 66, 4010-4015. doi:10.1016/j.tet.2010.04.052

34. Andriuzzi, O.; Gravier-Pelletier, C.; Vogel, P.; Le Merrer, Y. Tetrahedron 2005, 61, 7094-7104. doi:10.1016/j.tet.2005.05.066

35. Mehta, G.; Mohanrao, R.; Katukojvala, S.; Landais, Y.; Sen, S. Tetrahedron Lett. 2011, 52, 2893-2897. doi:10.1016/j.tetlet.2011.03.141

36. Andriuzzi, O.; Gravier-Pelletier, C.; Le Merrer, Y. Tetrahedron Lett. 2004, 45, 8043-8046. doi:10.1016/j.tetlet.2004.08.172

37. Andriuzzi, O.; Gravier-Pelletier, C.; Bertho, G.; Prange, T.; Le Merrer, Y. Beilstein J. Org. Chem. 2005, 1, No. 12. doi:10.1186/1860-5397-1-12

38. Grabowski, S.; Armbruster, J.; Prinzbach, H. Tetrahedron Lett. 1997, 38, 5485-5488. doi:10.1016/s0040-4039(97)01227-6

39. Byun, H.-S.; He, L.; Bittman, R. Tetrahedron 2000, 56, 7051-7091. doi:10.1016/s0040-4020(00)00494-4

40. Zou, J.; Ni, G.; Tang, J.; Yu, J.; Jiang, L.; Ju, D.; Zhang, F.; Chen, S. Eur. J. Org. Chem. 2018, 5044-5053. doi:10.1002/ejoc.201800658

\section{License and Terms}

This is an Open Access article under the terms of the Creative Commons Attribution License (https://creativecommons.org/licenses/by/4.0). Please note that the reuse, redistribution and reproduction in particular requires that the author(s) and source are credited and that individual graphics may be subject to special legal provisions.

The license is subject to the Beilstein Journal of Organic Chemistry terms and conditions: (https://www.beilstein-journals.org/bjoc/terms)

The definitive version of this article is the electronic one which can be found at: https://doi.org/10.3762/bjoc.17.59 